\title{
A STUDY OF COMPARISON OF SUBTENON'S ANAESTHESIA WITH PERIBULBAR ANAESTHESIA IN MANUAL SMALL INCISION CATARACT SURGERY IN RIMS TEACHING HOSPITAL RAICHUR
}

\section{H. Siddesh Kumar ${ }^{1}$, Kavita Patil ${ }^{* 2}$.}

${ }^{1}$ Associate professor, Department of Ophthalmology, RIMS, Raichur, Karnataka, India.

${ }^{*} 2$ Professor, Department of Ophthalmology, Gulbarga Institute Of Medical Sciences, Karnataka, India.

\section{ABSTRACT}

\begin{abstract}
Purpose: This study is being taken for comparing the efficacy and complications encountered between subtenon anaesthesia and peribulbar anaesthesia in manual small incision cataract surgery in RIMS teaching hospital Raichur.

Materials and Methods: This comparative study was done on 50 patients (group 1 subtenon anaesthesia $(n=25)$ and group 2 peribulbar anaesthesia $(n=25)$ ) with senile cataractwith visual acuity CF/HMundergoing lens extraction by manual small incision cataract surgery with posterior chamber intra ocular lens implantation atin the Department of Ophthalmology, RIMS teaching hospital Raichur.

Results: 56\% Subtenon's anaesthesia group patients, and 32\% Peribulbar anaesthesia group patients had no pain, when it compared it is statistically significant $(0.048), 20 \%$ Subtenon's anaesthesia group patients, and $64 \%$ Peribulbar anaesthesia group patients had no grade 0 , when it compared it is statistically significant (0.004), and 20\% Subtenon's anaesthesia group patients, and 64\% Peribulbar anaesthesia group patients had no grade 0 , when it compared it is statistically significant (0.004).

Conclusion: Subtenon's anaesthesia is a safe and effective substitute for preibulbar anaesthesia in Manualsmall incision cataract surgery.

KEY WORDS: Cataract surgery, Manualsmall incision cataract surgery, Subtenon's anaesthesia and Preibulbar anaesthesia.
\end{abstract}

Address for correspondence: Dr. Kavita Patil, Professor, Department of Ophthalmology, Gulbarga Institute Of Medical Sciences, Karnataka, India.

E-Mail: drsiddesh@gmail.com, kavi3009@gmail.com

\begin{tabular}{|c|c|c|}
\hline \multicolumn{3}{|c|}{ Online Access and Article Informtaion } \\
\hline \multirow{2}{*}{$\begin{array}{l}\text { Quick Response code } \\
\text { DOI: } 10.16965 \text { /ijims.2019.111 }\end{array}$} & \multicolumn{2}{|c|}{$\begin{array}{l}\text { International Journal of Integrative Medical Sciences } \\
\text { ISSN (P): } 2394 \text { - 6318. ISSN (E): } 2394-4137 \\
\text { www.imedsciences.com }\end{array}$} \\
\hline & $\begin{array}{l}\text { Received: 10-05-2019 } \\
\text { Reviewed: 10-05-2019 }\end{array}$ & $\begin{array}{l}\text { Accepted: 21-05-2019 } \\
\text { Published: 20-07-2019 }\end{array}$ \\
\hline Source of Funding: Self & \multicolumn{2}{|c|}{ Conflicts of interest: None } \\
\hline
\end{tabular}

\section{INTRODUCTION}

Normally, the lens of eye is clear but cataract causes the lens to become cloudycause blurry vision and increase the glare from lights, which eventually affects the vision, it difficult for to carry out normal activities in that situation cataract surgery is a procedure to remove the lens of eye and, replace it with an artificial lens is require.Cataract is the leading cause of preventable blindness in the world, and in India 50-80\% bilateral blindness, cataract surgery is perhaps the most effective and common surgical procedure in all of medicine [1]. Andis known to be the most cost effective of all surgical procedures [2]. In early years eye surgeries had been performed with little or no anesthesia, for 1000 years until 1884 when cocaine hydrochloride was discovered by carl koller [2].

Later it had been shifted from general anesthesia, sedation, and hospitalization to regional 
ophthalmic block, as well as topical anesthesia with OPD basis due to the improvement of cataract surgery techniquesare predicated on reduced surgical wound size and self sealing architecture as well as better intraocular lenses design, less tissue manipulation, and modern instrumentation [2]. The operative technique includes extracapsular cataract extraction (ECCE), manual small incision cataract surgery (MSICS; also, SICS or SECCE), phaco emulsification, and phacolaser methods [2]. MSICS is a low-cost, small-incision form of ECCE that is principally employed in the developing world. Compared to traditional ECCE, MSICS has the advantage of a self-sealing suture less wound. Recent investigations have shown, in resource poor settings MSICS also has several distinct advantages over phacoemulsification, including shorter operative time, less need for technology and lower cost andcomparable outcomes and complication rates [2].

In the MSICS use of shorter acting anaesthetic agents with less invasive methods of administration. Early days commonly used drug was Retrobulbar anesthesia, later it was replaced by peribulbar anesthesia because of the serious needle-related complications associated with the former such as retrobulbar haemorrhage, optic nerve damage, and globe perforation [3]. In present day practice Peribulbar anaesthesia and Subtenon anaesthesiaare commonly used for cataract extraction. However, peribulbar anaesthesiawas the most popular technique in the previous decade, does not eliminate serious complications totally, although these probably occur less frequently. Even with a two-injection technique, it has sometimes an excessive rate of imperfect blockade and pain.Alternative anaesthesia procedures have been developed to reduce the risk of injuring intraorbital structures [1]. Subtenon anaesthesia provided a quicker onset of anaesthesia, better akinesia and more consistency in effectiveness and better patient compliance. It involves transconjunctival infiltration of local anaesthetic agent directly to the subtenon's space, after instillation of local anaesthetic drop in the conjunctiva which takes away the pain from, the needle prick. This technique has been used forconventional extracapsular cataract extraction (ECCE) with posterior chamber intraocular lens implantation ( $\mathrm{PCIOL}$ )and phacoemulsification [1]. Manualsmall incision cataract surgery (MSICS) has become popular in developing countries like India. This study is being taken for comparing the efficacy and complications encountered between subtenon anaesthesia and peribulbar anaesthesia in manual small incision cataract surgery in RIMS teaching hospital Raichur.

\section{MATERIALS AND METHODS}

This comparative study was done on 50 patients with senile cataractwith visual acuity CF/ HMundergoing lens extraction by manual small incision cataract surgery with posterior chamber intra ocular lens implantation atin the Department of Ophthalmology, RIMS teaching hospital Raichur. After obtain of institutional ethical committee approval patients were included in the study, they were randomized into two groups, group 1 subtenon anaesthesia $(n=25)$ and group 2 peribulbar anaesthesia $(n=25)$.A complete ophthalmic examination including best corrected visual acuity, dilated fundus evaluation was done for all patients. All the patients undergoing cataract surgery after obtaining general medicine clearance were included in the study. Patients Signs of chronic ocular inflammation - uveitis, traumatic/complicated cataract, Subluxated lens, Lens induced glaucoma, Diabetes mellitus, and Hypertensionexcluded from the study.

Administration of anaesthesia: For peribulbar anaesthesia, the eye was painted with $10 \%$ povidone-iodine solution and draped. Lid speculum was placed. $7 \mathrm{ml}$ of anesthetic mixture was prepared with $4 \mathrm{ml}$ of combination of $2 \%$ lignocaine and 1:200000 units of adrenaline and $3 \mathrm{ml}$ of $0.5 \%$ bupivacaine. $4 \mathrm{ml}$ of the anesthetic mixture was injected using $23 \mathrm{G}$ needle at the junction of outer one-third and inner two-third of the lower orbital margin with the needle directed toward the floor of the orbit. An additional $3 \mathrm{ml}$ injection was given at the supraorbital notch using a 23G needle till the hub of the needle if required. Eyelids were then closed, and intermittent pressure was applied for 5 min. For subTenon's anesthesia eye was painted with $10 \%$ povidone-iodine solution and draped. Lid speculum was placed. A volume of $5 \mathrm{ml}$ of anesthetic 
mixture was prepared with $3 \mathrm{ml}$ of combination of 2\% lignocaine and 1:200000 units of adrenaline and $2 \mathrm{ml}$ of $0.5 \%$ bupivacaine. $0.5 \%$ of topical proparacaine was instilled.The patient was instructed to look upward and inwards. By using scissors made a small nick in the conjunctiva and Tenon's capsule in the inferotemporal quadrant. Sub-Tenon's cannula was then inserted to bare sclera and guided along the contour of the globe till the hub of the needle touches thesclera. $3 \mathrm{ml}$ of the anesthetic mixture was slowly injected into this sub-Tenon's space.

After the procedure the efficacy and safety of two methods of anaesthesia in MSICS with respect to pain, akinesia, time of onset, duration and complications are noted and compared.After giving the block the time of onset of akinesia was noted and scored based on eye movements: $0=$ Few or no eye movements after initiation of procedure, 1 = Occasional eye movements lasting only a few seconds, and 2 = Constant roving eye movements.The grading of pain was done as follow; Grade $0=$ No pain, grade $1=$ No pain, slight sensation, grade $2=$ slight pain, grade 3 $=$ Moderate pain, and grade $4=$ Intense pain.Scoring of lid movements during surgery; 0 = Little or no lid squeezing, 1 = Moderate or ill sustained squeezing throughout, and 2 = Instantaneous and sustained squeezing.The ophthalmologists also graded for chemosis, Grade $0=$ No chemosis, grade 1 = chemosis in single quadrant, grade 2 = chemosis in 2 quadrants, grade $3=$ chemosis in 3 quadrants, and grade $4=$ chemosis in all quadrants. And subconjunctival haemorrhage after administration of anaesthesia Grade $0=$ No haemorrhage, grade $1=$ haemorrhage in single quadrant, grade $2=$ haemorrhage in 2 quadrants, grade $3=$ haemorrhage in 3 quadrants, and grade $4=$ haemorrhage in all quadrants.

\section{RESULTS}

Table 1: Showing the comparison of pain in two groups.

\begin{tabular}{|c|c|c|c|c|}
\hline \multirow{2}{*}{ Grading of pain } & \multicolumn{2}{|c|}{$\begin{array}{c}\text { Subtenon's anaesthesia } \\
\text { group }\end{array}$} & \multicolumn{2}{c|}{$\begin{array}{c}\text { Peribulbar anaesthesia } \\
\text { group }\end{array}$} \\
\cline { 2 - 5 } & $\begin{array}{c}\text { Number of } \\
\text { cases }\end{array}$ & $\begin{array}{c}\text { Percentage } \\
(\%)\end{array}$ & $\begin{array}{c}\text { Number of } \\
\text { cases }\end{array}$ & $\begin{array}{c}\text { Percentage } \\
(\%)\end{array}$ \\
\hline Grading 0 & 14 & 56 & 8 & 32 \\
\hline Grading 1 & 7 & 28 & 6 & 24 \\
\hline Grading 2 & 4 & 16 & 9 & 36 \\
\hline Grading 3 & 0 & 0 & 1 & 4 \\
\hline Grading 4 & 0 & 0 & 1 & 4 \\
\hline
\end{tabular}

Int J Intg Med Sci 2019;6(4):807-11. ISSN 2394 - 4137
$56 \%$ Subtenon's anaesthesia group patients, and $32 \%$ Peribulbar anaesthesia group patients had no pain, when it compared it is statistically significant (0.048).

Fig. 1: Comparison of pain in two groups.

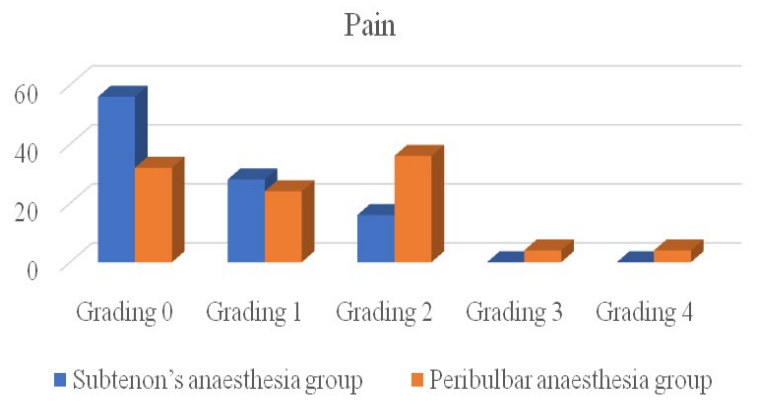

Table 2: Showing the comparison of Grading of Akinesia in two groups.

\begin{tabular}{|c|c|c|c|c|}
\hline \multirow{2}{*}{$\begin{array}{c}\text { Grading of } \\
\text { Akinesia }\end{array}$} & \multicolumn{2}{|c|}{ Subtenon's anaesthesia group } & \multicolumn{2}{c|}{ Peribulbar anaesthesia group } \\
\cline { 2 - 5 } & $\begin{array}{c}\text { Number of } \\
\text { cases }\end{array}$ & Percentage (\%) & Number of cases & $\begin{array}{c}\text { Percentage } \\
(\%)\end{array}$ \\
\hline Grading 0 & 5 & 20 & 16 & 64 \\
\hline Grading 1 & 11 & 44 & 5 & 20 \\
\hline Grading 2 & 9 & 36 & 4 & 16 \\
\hline
\end{tabular}

$20 \%$ Subtenon's anaesthesia group patients, and $64 \%$ Peribulbar anaesthesia group patients had no grade 0, when it compared it is statistically significant (0.004).

Fig. 2: Comparison of Grading of Akinesia in two groups. Akinesia

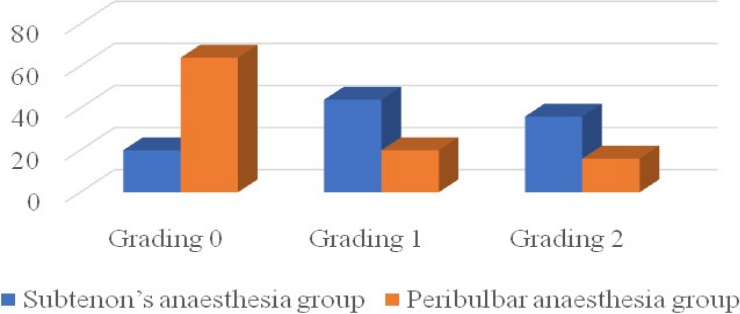

Table 3: Showing the comparison of Intra Operative Lid Movements in two groups.

\begin{tabular}{|c|c|c|c|c|}
\hline \multirow{2}{*}{$\begin{array}{c}\text { Grading of Intra Operative } \\
\text { Lid Movements }\end{array}$} & \multicolumn{2}{|c|}{$\begin{array}{c}\text { Subtenon's anaesthesia } \\
\text { group }\end{array}$} & \multicolumn{2}{c|}{$\begin{array}{c}\text { Peribulbar anaesthesia } \\
\text { group }\end{array}$} \\
\cline { 2 - 5 } & $\begin{array}{c}\text { Number of } \\
\text { cases }\end{array}$ & $\begin{array}{c}\text { Percentage } \\
(\%)\end{array}$ & $\begin{array}{c}\text { Number of } \\
\text { cases }\end{array}$ & $\begin{array}{c}\text { Percentage } \\
(\%)\end{array}$ \\
\hline Grading 0 & 22 & 88 & 17 & 68 \\
\hline Grading 1 & 3 & 12 & 8 & 32 \\
\hline Grading 2 & 0 & 0 & 0 & 0 \\
\hline
\end{tabular}

Fig. 3: Comparison of Intra Operative Lid Movements in two groups.

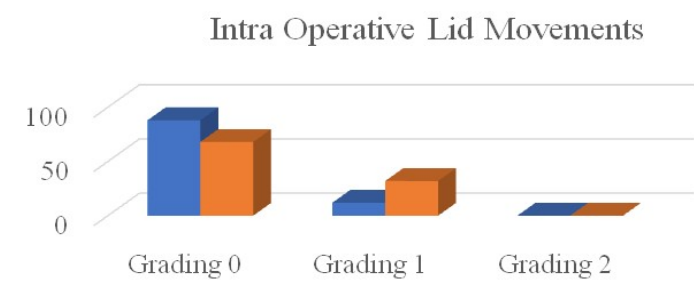

E Subtenon's anaesthesia group = Peribulbar anaesthesia group 
$88 \%$ Subtenon's anaesthesia group patients, and $68 \%$ Peribulbar anaesthesia group patients had no grade 0 , when it compared it is statistically significant (0.091).

Table 4: Showing the comparison of Chemosisin two groups.

\begin{tabular}{|c|c|c|c|c|}
\hline \multirow{2}{*}{$\begin{array}{c}\text { Grading of } \\
\text { Chemosis }\end{array}$} & \multicolumn{2}{|c|}{$\begin{array}{c}\text { Subtenon's anaesthesia } \\
\text { group }\end{array}$} & \multicolumn{2}{c|}{$\begin{array}{c}\text { Peribulbar anaesthesia } \\
\text { group }\end{array}$} \\
\cline { 2 - 5 } & $\begin{array}{c}\text { Number of } \\
\text { cases }\end{array}$ & $\begin{array}{c}\text { Percentage } \\
(\%)\end{array}$ & $\begin{array}{c}\text { Number of } \\
\text { cases }\end{array}$ & $\begin{array}{c}\text { Percentage } \\
(\%)\end{array}$ \\
\hline Grading 0 & 14 & 56 & 16 & 64 \\
\hline Grading 1 & 8 & 32 & 5 & 20 \\
\hline Grading 2 & 2 & 8 & 3 & 12 \\
\hline Grading 3 & 1 & 4 & 1 & 4 \\
\hline Grading 4 & 0 & 0 & 0 & 0 \\
\hline
\end{tabular}

$56 \%$ Subtenon's anaesthesia group patients, and 64\% Peribulbar anaesthesia group patients had no grade 0 , when it compared it is statistically significant (0.706).

Fig. 4: Comparison of Chemosis in two groups.

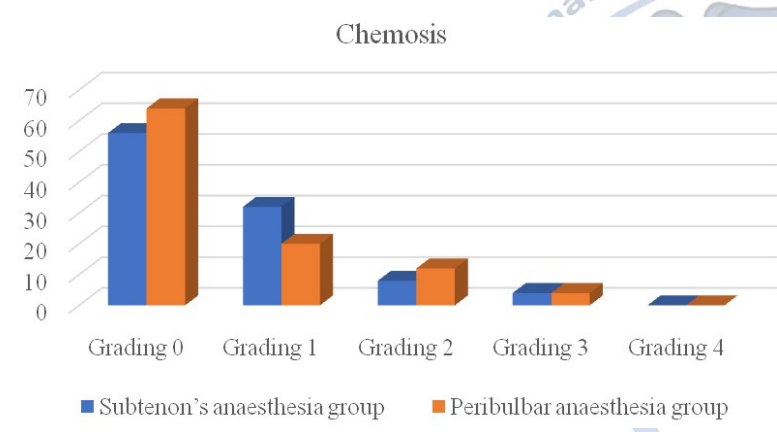

Table 5: Showing the comparison of Haemorrhage in two groups.

\begin{tabular}{|c|c|c|c|c|}
\hline \multirow{2}{*}{$\begin{array}{c}\text { Grading of } \\
\text { Haemorrhage }\end{array}$} & \multicolumn{2}{|c|}{$\begin{array}{c}\text { Subtenon's anaesthesia } \\
\text { group }\end{array}$} & \multicolumn{2}{|c|}{$\begin{array}{c}\text { Peribulbar anaesthesia } \\
\text { group }\end{array}$} \\
\cline { 2 - 5 } & $\begin{array}{c}\text { Number of } \\
\text { cases }\end{array}$ & $\begin{array}{c}\text { Percentage } \\
\text { (\%) }\end{array}$ & $\begin{array}{c}\text { Number of } \\
\text { cases }\end{array}$ & $\begin{array}{c}\text { Percentage } \\
\text { (\%) }\end{array}$ \\
\hline Grading 0 & 12 & 48 & 15 & 60 \\
\hline Grading 1 & 10 & 40 & 6 & 24 \\
\hline Grading 2 & 2 & 8 & 3 & 12 \\
\hline Grading 3 & 1 & 4 & 1 & 4 \\
\hline Grading 4 & 0 & 0 & 0 & 0 \\
\hline
\end{tabular}

Fig. 5: Comparison of Haemorrhage in two groups.

\section{Haemorrhage}

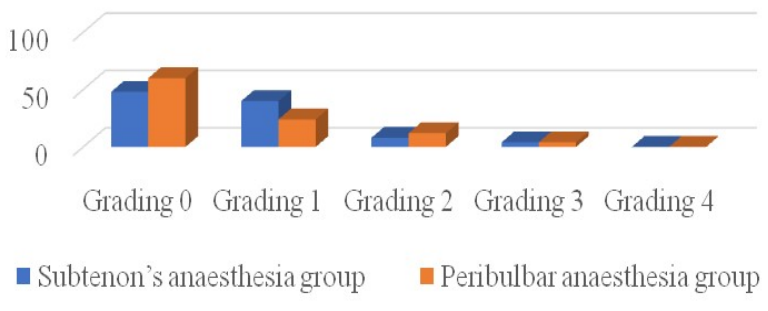

$48 \%$ Subtenon's anaesthesia group patients, and $60 \%$ Peribulbar anaesthesia group patients had no grade 0 , when it compared it is statistically significant (0.370).

\section{DISCUSSION}

Subtenon's anaesthesia was more comfortable for the patient at the time of anaesthetic administration. It offers a significantly reduced risk of complication such as scleral perforation and injection of anaesthetic solution into subarachnoid space as no sharp instrument is passed into orbit. Subtenon's technique for administration of anaesthesia during MSICS is as safe as the peribulbar technique giving equally good analgesia during and after surgery. The technique of blunt dissection and the type of cannula used to perform the block avoid potentially serious side effects of retro or peribulbar blocks. Subtenon's anaesthesia provided a more constantly effective block than did with peribulbar anaesthesia with shorter time to onset of blockade, better maximal akinesia and no need of supplement injection [4].

In the present study in subtenon group $56 \%$ of patients and Peribulbar group 32\% experienced grade 0 pain and none of the subtenon group patients and 4\%Peribulbar group patients had grade 4 pain. Authors observations with regard
Table 6: Showing p-values of the comparison of Akinesia, Pain, Intra Operative Lid Movements, Haemorrhage, and Chemosis in two groups.

\begin{tabular}{|c|c|c|c|c|c|c|c|}
\hline \multicolumn{2}{|c|}{ Drug } & $\mathrm{N}$ & Mean Rank & Sum of Ranks & $\begin{array}{c}\text { Mann- } \\
\text { Whitney U }\end{array}$ & $z$ & P-value \\
\hline \multirow{2}{*}{ Akinesia } & SUBTENON'S & 25 & 31.02 & 775.5 & \multirow{2}{*}{174.5} & \multirow{2}{*}{-2.861} & \multirow{2}{*}{0.004} \\
\hline & PERIBULBAR & 25 & 19.98 & 499.5 & & & \\
\hline \multirow{2}{*}{ pain } & SUBTENON'S & 25 & 21.78 & 544.5 & \multirow{2}{*}{219.5} & \multirow{2}{*}{-1.978} & \multirow{2}{*}{0.048} \\
\hline & PERIBULBAR & 25 & 29.22 & 730.5 & & & \\
\hline \multirow{2}{*}{$\begin{array}{l}\text { Intra Operative Lid } \\
\text { Movements }\end{array}$} & SUBTENON'S & 25 & 23 & 575 & \multirow{2}{*}{250} & \multirow{2}{*}{-1.69} & \multirow{2}{*}{0.091} \\
\hline & PERIBULBAR & 25 & 28 & 700 & & & \\
\hline \multirow{2}{*}{ Haemorrhage } & SUBTENON'S & 25 & 27.18 & 679.5 & \multirow{2}{*}{270.5} & \multirow{2}{*}{-0.897} & \multirow{2}{*}{0.37} \\
\hline & PERIBULBAR & 25 & 23.82 & 595.5 & & & \\
\hline \multirow{2}{*}{ Chemosis } & SUBTENON'S & 25 & 26.18 & 654.5 & \multirow{2}{*}{295.5} & \multirow{2}{*}{-0.377} & \multirow{2}{*}{0.706} \\
\hline & PERIBULBAR & 25 & 24.82 & 620.5 & & & \\
\hline
\end{tabular}


to intra operative pain were consistent with studies done by Matcha SCet al. [5], Parkar T. et al. [1], and Datta A. et al. [3], who found that subtenon's anesthesia was superior to peribulbar anaesthesia in the controlling pain. In this study $20 \%$ grade 0 and $44 \%$ grade 1 in the subtenon's group and $64 \%$ grade 0 and $20 \%$ grade 1 in the peribulbar group patients had akinesia.These findings with respect to intra operative akinesia were slightly superior to the findings in the study Matcha SC et al [5], and Parkar T. et al. [1].

In this study showing that $56 \%$ grade 0 and $0 \%$ grade 4 in the subtenon's group and $64 \%$ grade 0 and $0 \%$ grade 4 in the peribulbar group patients had experienced chemosis respectively. $48 \%$ grade 0 and $0 \%$ grade 4 in the subtenon's group and $60 \%$ grade 0 and $0 \%$ grade 4 in the peribulbar group patients had experienced Haemorrhage respectively. These findings were supporting the Matcha SC et al. [5] reports.

\section{CONCLUSION}

The administration of subtenon's block was painless and no pain during surgery. There was no akinesia when assessed just after the completion of block and akinesia was limited when assessed after surgery. Chemosis and conjunctival haemorrhage were frequent but caused no intra operative problem. Subtenon's block is a simple, effective, relatively safe and versatile technique. Sub-Tenon's anaesthesia is a safe and effective substitute for preibulbar anaesthesia in Manualsmall incision cataract surgery.

\section{REFERENCES}

[1]. Parkar T, Gogate P, Deshpande M, Adenwala A, Maske A, Verappa K. Comparison of subtenon anaesthesia with peribulbar anaesthesia for manual small incision cataract surgery. Indian J Ophthalmol.2005;53:255-9.

[2]. Adekola O O, Aribaba OT, Musa K, Olatosi JO, Asiyanbi GK, Rotimi Samuel A, et al. Regional anesthesia for small incision cataract surgery: Comparison of subtenon and peribulbar block. J Clin Sci.2018;15:1 7.

[3]. Datta A, Ghosh K, Basu S. A Comparative eveluation of peribulbar, subtenon's and topical anaesthesia. AIOC Proc. 2008;82.

[4]. Ripart J, Lefrant J, Vivien B, Charavel P, Fabbroperay $P$, JaussaudA, etal. Ophthalmic regional anaesthesia. Medial canthus episcleral (subtenon) anaesthesia is more efficient than peribulbar anaesthesia. Anaesthesiology.2000;92:1278-85.

[5]. Matcha SC, Nandyala SKK, Murahari VK. Comparison of subtenon's v/s peribulabar anesthesia in manual small incision cataract surgery cases. MRIMS J Health Sciences. 2015;3(1):68-70.

How to cite this article: $\mathrm{H}$. Siddesh Kumar, Kavita Patil. A STUDY OF COMPARISON OF SUBTENON'S ANAESTHESIA WITH PERIBULBAR ANAESTHESIA IN MANUAL SMALL INCISION CATARACT SURGERY IN RIMS TEACHING HOSPITAL RAICHUR. Int J Intg Med Sci 2019;6(4):807811. DOI: $10.16965 /$ ijims.2019.111 